\title{
Improving irrigation, crop, and soil management for sustainable soybean production
}

\section{in Southern Brazilian lowlands}

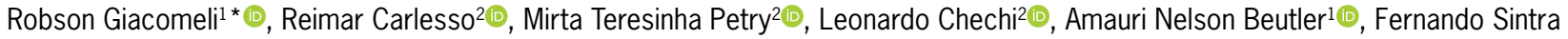

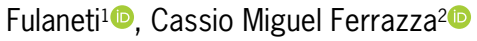

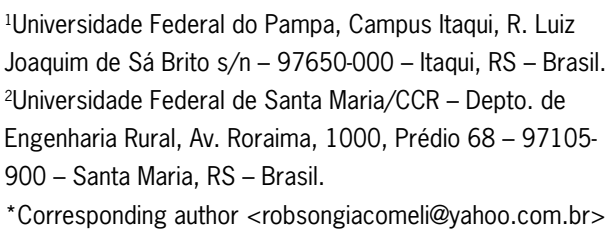

Edited by: Paulo Cesar Sentelhas/Thiago Libório Romanelli

Received May 10, 2021

Accepted September 06, 2021
ABSTRACT: Lowlands have been cultivated with irrigated rice (Oryza sativa) in a monoculture cropping system for more than a century in southern Brazil. Shallow topsoil with high bulk density and deficient water infiltration favors the of production paddy rice; however, this condition does not favor species non-tolerant to flooding or oxygen restriction. Thus, soil and irrigation management may be necessary to raise the rice-soybean (Glycine max) rotation systems to sustainable levels. We carried out a two-year field experiment to assess the effects of irrigation treatments and soil management on soil physical properties, soybean growth, and grain yield in lowland systems. The experiment comprised a randomized block design with two factors and three replications. The main factor comprised the following irrigation treatments: sprinkler; surface, and rainfed. Four soil managements composed the second factor: conventional tillage (CT), no-tillage (NT), conventional tillage with raised-seedbed, and no-tillage with raised-seedbed. Soil physical properties, soil penetration resistance, crop parameters, grain yield and water productivity were evaluated. $\mathrm{CT}$ increased the soil penetration resistance near the soil surface layer. The highest soil bulk density at the $0.05-0.10 \mathrm{~m}$ layer in the CT reduces grain yield in rainfed soybean compared to NT. Supplementary irrigation increased soybean yield of about $36 \%$ in years of uneven rainfall distribution. Sprinkler irrigation resulted in higher irrigated water productivity ( $90 \%$ ) compared to surface irrigation, contributing to a more sustainable increase in grain yield. Crop rotation in a no-tillage cropping scheme could improve the sustainability of diversified agriculture in lowlands.

Keywords: raised-seedbed, conventional tillage, no-tillage, water productivity

\section{Introduction}

Lowlands have been used for irrigated rice (Oryza sativa) production for more than a century in southern Brazil due to their favorable features, such as low water infiltration and macroporosity in the soil layer near the surface (Sartori et al., 2016; Denardin et al., 2019). In the southern region of Rio Grande do Sul State (RS), lowlands cover almost 6.5 million ha (Miura et al., 2015) of which 1 million ha are annually cultivated with flooded rice (Conab, 2020).

Although most lowland fields are leveled to enhance the efficiency of flooded rice production, the recent boom of soybean (Glycine max) production shifted these wetlands to rainfed crops, mainly soybean. Little increase in grain yield in flooded rice lately, along with weed resistance to the major herbicides available for rice production (Rao et al., 2007), seems to contribute to yield stabilization of about $7.5 \mathrm{Mg} \mathrm{ha}^{-1}$ (Conab, 2020). Rotating rice with soybean or corn crops can control weed (Fin et al., 2018; Giacomeli et al., 2017); nevertheless, less than $33 \%$ of the lowlands have been rotated with other grain crops (Theisen et al., 2017).

The soil physical properties that favor paddy fields can increase the risk of either soil water excess or deficit by limiting soil aeration and water availability, decreasing soybean yields in lowlands (Gubiani et al., 2018). Therefore, cultivation strategies, such as soil chiseling, raised-seedbed or the use of furrow opener at the row planter (Sartori et al., 2016; Giacomeli et al., 2017) may create better conditions for soybean development, improving its yields close to the gains achieved in uplands.

Different irrigation methods are indicated to avoid crop water stress and ensure greater crop yield. The surface irrigation method is a low-cost alternative and maintains the same structures used for flooded rice, already available in these fields. However, to ensure the minimum soil aeration, the use of raised-seedbed might be necessary to grow soybean in this environment, even when using surface irrigation (Gubiani et al., 2018). Center-pivot sprinkler irrigation allows using upland crops in a no-tillage system in lowlands, in rotation with rice. Besides, the center pivoting requires less labor and its more water-saving than the surface methods (Sánchez-Llerena et al., 2016). Therefore, this study aims to assess the effects of different irrigation treatments and soil management on soil physical properties, soybean growth, and grain yield in lowland systems.

\section{Materials and Methods}

Two experiments were carried out in the same field at $29^{\circ} 09^{\prime} 38^{\prime \prime} \mathrm{S}, 56^{\circ} 33^{\prime} 17^{\prime \prime} \mathrm{W}$ and altitude $74 \mathrm{~m}$, during the 2016/17 (ExpI) and 2017/18 (ExpII) soybean crop seasons. According to Köppen classification, the 
climate is characterized as subtropical humid (Cfa), without a defined dry season and an annual rainfall of $1750 \mathrm{~mm}$ (Alvares et al., 2013). The meteorological conditions (Figure 1) were obtained from an automated weather station (Vantage Pro2, Davis, USA), near the experimental site. The soil is classified as Plinthudult (Soil Survey Staff, 2014), and the physical and chemical characteristics are given in Table 1 .
The experimental site was pre-prepared during Apr and June in 2016 to implement the no-tillage system. The topsoil layer was cultivated and leveled twice using a disk harrow. Experiment I (ExpI) was implemented in Aug, in which $3.5 \mathrm{Mg} \mathrm{ha}^{-1}$ of limestone $(60 \%$ calcium carbonate equivalent) was applied to increase the soil $\mathrm{pH}$ to 6.0. After liming (on 10 Aug 2016), a chiseling till $0.3 \mathrm{~m}$ depth with shanks spaced at $0.35 \mathrm{~m}$ was

Table 1 - Soil physical and chemical characteristics $(0-0.2 \mathrm{~m})$, before the study installation.

\begin{tabular}{|c|c|c|c|c|c|c|c|c|c|}
\hline \multirow{2}{*}{ Soil layer } & \multirow{2}{*}{$\mathrm{BD}$} & \multirow{2}{*}{$\mathrm{TP}$} & \multirow{2}{*}{$\mathrm{Mi}$} & \multirow[b]{2}{*}{ Ma } & \multirow{2}{*}{$\theta_{\mathrm{FC}}$} & \multirow[b]{2}{*}{$\theta_{\mathrm{WP}}$} & \multicolumn{3}{|c|}{ Texture } \\
\hline & & & & & & & Sand & Silt & Clay \\
\hline $\mathrm{m}$ & $\mathrm{Mg} \mathrm{m}^{-3}$ & - & 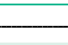 & $\mathrm{m}^{3} \mathrm{~m}^{-}$ & 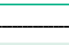 & 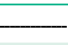 & 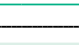 & $-g k$ & 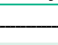 \\
\hline $0.0-0.1$ & 1.49 & 0.42 & 0.30 & 0.12 & 0.28 & 0.09 & 585 & 237 & 179 \\
\hline $0.1-0.2$ & 1.78 & 0.32 & 0.30 & 0.02 & 0.28 & 0.11 & 570 & 225 & 204 \\
\hline $0.2-0.3$ & 1.74 & 0.33 & 0.30 & 0.03 & 0.28 & 0.11 & 526 & 199 & 275 \\
\hline $0.3-0.4$ & 1.60 & 0.38 & 0.34 & 0.04 & 0.32 & 0.15 & 501 & 157 & 342 \\
\hline $0.4-0.5$ & 1.54 & 0.41 & 0.33 & 0.08 & 0.31 & 0.18 & 460 & 157 & 383 \\
\hline
\end{tabular}

Chemical

\begin{tabular}{|c|c|c|c|c|c|c|c|}
\hline $\mathrm{pH}\left(\mathrm{H}_{2} \mathrm{O} \quad 1: 1\right)$ & $\mathrm{OM}$ & K & $\mathrm{P}$ & $S$ & $\mathrm{CEC}_{\mathrm{pH} 7}$ & Saturation by Al & Saturation by bases \\
\hline & & & & & $\mathrm{cmol}_{\mathrm{c}} \mathrm{dm}^{-3}$ & & \\
\hline 5.3 & 18 & 36.0 & 3.6 & 19.4 & 6.5 & 5.1 & 56.4 \\
\hline
\end{tabular}

$\mathrm{BD}=$ Bulk density; $\mathrm{TP}=$ Total porosity; $\mathrm{Mi}=$ Microporosity; $\mathrm{Ma}=$ Macroporosity; $\theta_{\mathrm{FC}}=$ Field Capacity at $-0.33 \mathrm{MPa} ; \theta_{\mathrm{WP}}=$ Permanent Wilting Point, at $-1.5 \mathrm{MPa}$; OM $=$ Organic Matter; $\mathrm{CEC}=$ Cation exchange capacity

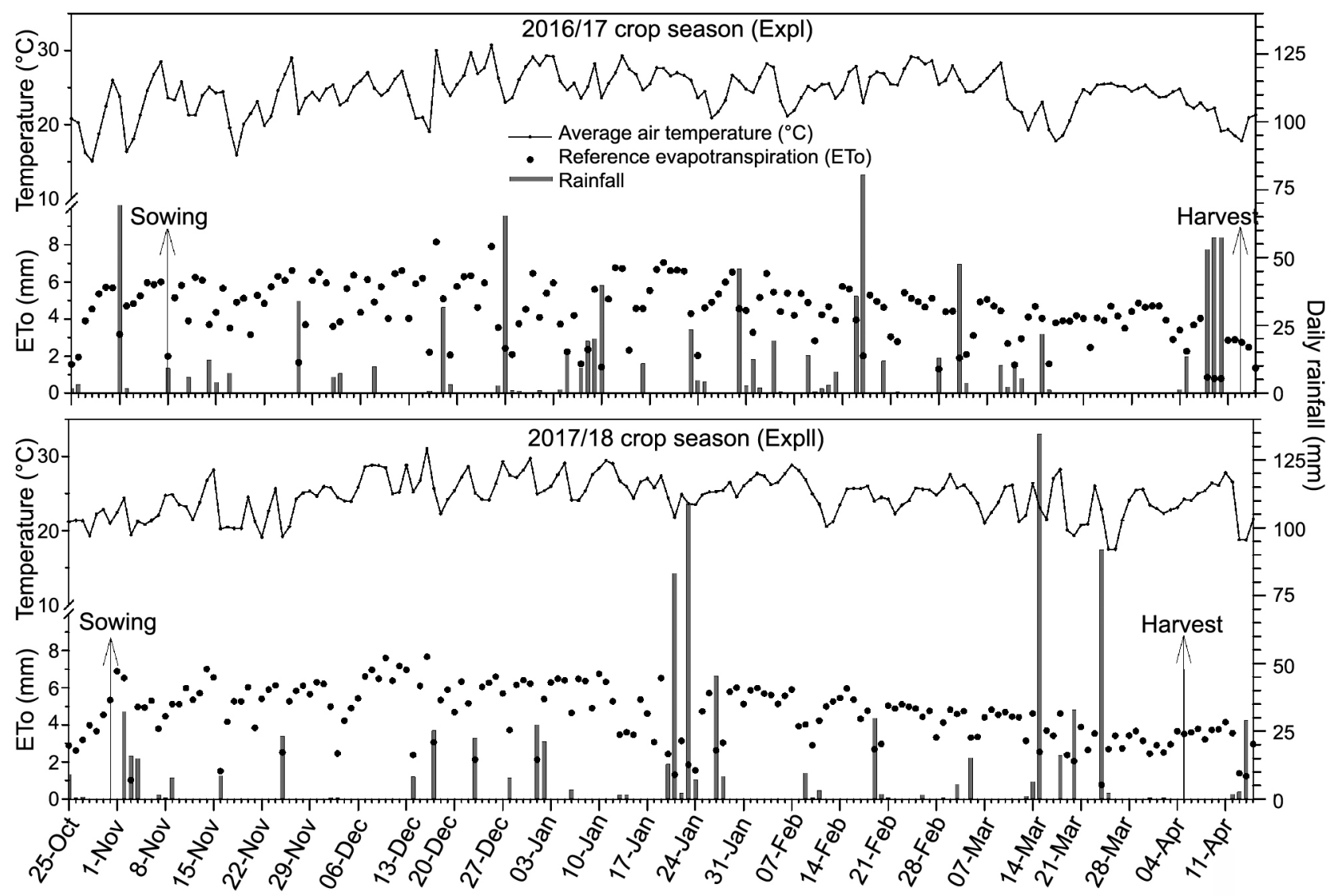

Figure 1 - Average air temperature, reference evapotranspiration (ETo), and rainfall in 2016/17 and 2017/18 crop seasons. 
carried out, followed the sowing of black oats in the experimental site on the same day. For experiment II (ExpII), in 2017, black oats was sown in June using a seed drill for no-tillage with rows spaced at $0.17 \mathrm{~m}$.

A randomized block design system with two factors $(3 \times 4)$ and three replications were used. The main factor comprised the irrigation treatments: sprinkler, surface, and control treatment (rainfed). The second factor was composed of four soil managements: conventional tillage $(\mathrm{CT})$, no-tillage $(\mathrm{NT})$, conventional tillage with raised-seedbed (SCT), and no-tillage with raised-seedbed (SNT). For CT and SCT, the soil was discharrowed twice, followed by soil leveling on 31 Oct 2016 (Exp1) and 05 Oct 2017 (Exp2).

The raised-seedbeds with $0.15 \mathrm{~m}$ high and $1 \mathrm{~m}$ spaced were built on this same day for SCT. For SNT, the raised-seedbeds were built after the soil chiseling (Aug 2016). In CT and NT without raised-seedbeds, irrigations were performed using the border strip system, while in SCT and SNT, furrow irrigation was used.

The soybean cultivar Brasmax 63164RSF was sown on 08 Nov 2016 and 31 Oct 2017, using plant populations of 30 and 24 seeds $\mathrm{m}^{-2}$, respectively. A rowplanter equipped with a $0.14 \mathrm{~m}$ depth furrow opener spaced at $0.5 \mathrm{~m}$ between rows was used. The residues of black oats on the soil surface in NT and SNT treatments was 2.4 and $4.5 \mathrm{Mg} \mathrm{ha}^{-1}$, in 2016 and 2017, respectively. The crop was fertilized and cultivated following the recommendations for a $6 \mathrm{Mg} \mathrm{ha}^{-1}$ grain yield (Salvadori et al., 2016).

The irrigation management was determined for all treatments using a combination of the crop evapotranspiration $\left(\mathrm{ET}_{\mathrm{c}, \mathrm{mm} \mathrm{d}} \mathrm{mm}^{-1}\right)$ and the observed soil water content $\left(\theta, \mathrm{m}^{3} \mathrm{~m}^{-3}\right)$. The ET $\mathrm{c}$ was estimated using the $\mathrm{K}_{\mathrm{c}}-\mathrm{ET}_{\mathrm{o}}$ approach (Allen et al., 1998), where the $\mathrm{K}_{\mathrm{c}}$ is the single crop coefficient and $\mathrm{ET}_{\mathrm{o}}$ is the reference evapotranspiration, which was estimated using the Penman-Monteith method.

The $\theta$ was monitored with a set of FDR sensors installed in each plot, model CS616 (Campbell Scientific, Logan, UT, USA), which uses the time domain capacitance/frequency technique. However, for experiment I, $\theta$ was measured with a portable FDR, with a $20 \mathrm{~cm}$ length probe (HydrosenseTM, Campbell Scientific, Logan, UT, USA). For both experiments, measurements were made three times a week. Therefore, irrigations were performed whenever $\theta$ in the $0.25 \mathrm{~m}$ layer reached $0.193 \mathrm{~m}^{3} \mathrm{~m}^{-3} / \sim 70 \%$ of the $\left.\theta_{\mathrm{FC}}\right)$ or, alternately, when the cumulative $\mathrm{ET}_{\mathrm{c}}$ reached $25 \mathrm{~mm}$, which corresponded approximately to $55 \%$ of the allowed soil water depletion (RAW $=$ TAW. $p$ ), where RAW is the readily available water, TAW is the total available water, and $p$ is the soil water depletion for no stress, according to Allen et al. (1998).

We used a portable-sprinkler system, with $180^{\circ}$ part-circles sprinklers, model Pingo ${ }^{\circledR}$ (Fabrimar Ltda, Joinville, BRA) spaced at $10 \mathrm{~m}$. We installed four manifolds upstream of each plot, spaced at $1 \mathrm{~m}$ for the border strip irrigation (used on the CT and NT treatment). For the raised-seedbeds, in SCT and SNT, a manifold was installed at the upstream side of each furrow, for furrows spaced at $1 \mathrm{~m}$. The applied net irrigation depths for the sprinkler system were $12 \mathrm{~mm}$ ( $\pm 4 \mathrm{~mm}$ ), considering a uniformity coefficient of $85 \%$. In contrast, for the surface irrigation (border strip and furrows), irrigation depths fixed $30 \mathrm{~mm}$, for a coefficient of uniformity of $50 \%$.

The uniformity coefficient for the sprinkler system (Christiansen, 1942) was field checked, using catch cans $0.08 \mathrm{~m}$ tall and diameter and arranged in a square grid of $1 \mathrm{~m}$. The distribution uniformity for surface irrigation systems was determined by the basic infiltration rate and by the advance time, determined previously to implement the first experiment.

The soil physical properties were determined by collecting soil core samples at layers at 0.00-0.05, 0.05-0.1, and 0.1-0.2 $\mathrm{m}$ depth, using soil core samplers of about $0.040 \mathrm{~m}$ tall and $0.055 \mathrm{~m}$ of diameter. The samplings were carried out at two times: at about 60 days after sowing in ExpI and after harvesting in ExpII. Soil attributes, such as bulk density (BD), total porosity (TP), macroporosity (Ma), Microporosity (Mi) were the variables analyzed.

The soil resistance penetration $(\mathrm{RP})$ was evaluated in soil core samples with an average soil water content of $0.21 \mathrm{~m}^{3} \mathrm{~m}^{-3}(-100 \mathrm{kPa})$, with three replications for each sample, using an electronic penetrometer, following the methodology proposed by Silva et al. (2014). A 4-mm diameter cone point was used, penetrating soil samples up to a depth of $30 \mathrm{~mm}$, with a constant speed of $10 \mathrm{~mm}$ $\mathrm{min}^{-1}$ and readings saved at every second.

For ExpII, the following crop variables were observed at R5 stage (Fehr et al., 1977): root system distribution, plants height, pods per plant, shoot dry biomass $\left(0.5 \mathrm{~m}^{2}\right)$, harvest index, the number of nodules, and dry matter of root nodules per plant (among five plants). A trench with a $1.5 \mathrm{~m}$ width, perpendicular to two rows of plants, was caved in each plot to evaluate the effective root distribution and root depth. Pictures were taken using a frame of 1.0 by $0.4 \mathrm{~m}$ with a grid mesh of 0.05 by $0.05 \mathrm{~m}$ to expose the roots. At harvest, the plant height (up to the insertion of the last pod) and the number of pods per plant in $1.0 \mathrm{~m}^{2}$ were analyzed. The harvest index was determined by the ratio between grain yield and shoot dry matter.

Grain yield, water productivity and irrigated water productivity were analyzed in ExpI and ExpII. Grain yield was evaluated in a $6.0 \mathrm{~m}^{2}$ area, adjusting grain weight to a moisture of $13 \%$, the market moisture for soybean storing. Water productivity $\left(\mathrm{WP}, \mathrm{kg} \mathrm{m}^{-3}\right)$ is the actual grain yield $\left(\mathrm{Y}_{\mathrm{a}^{\prime}}, \mathrm{kg} \mathrm{ha}^{-1}\right)$ above the total water use $\left(T W U, \mathrm{~m}^{3}\right)$. In this case, TWU was the sum of the irrigation and the effective precipitation. Irrigation water productivity $\left(\mathrm{WP}_{\mathrm{IR}}, \mathrm{kg} \mathrm{m}^{-3}\right)$, on the other hand, is the ratio of the $\mathrm{Y}_{\mathrm{a}}$ and the total irrigation water use (IWU, $\mathrm{m}^{3}$ ). 
The results were submitted to the presuppositions test of the mathematical model (normality and homogeneity). The analysis of variance was performed by the $\mathrm{F}$ test $(p<0.05)$. When significant variance was observed in the analysis, the complementary Tukey test $(p<0.05)$ was performed. For the statistical analysis and for the presentation of the results in graphs, the software $R$, version 3.5.1, was used ( $R$ Core Team, 2018) with ExpDes.pt package (Ferreira et al., 2014).

\section{Results and Discussion}

No interaction between the factors (irrigation and soil management) was observed for $\mathrm{BD}, \mathrm{TP}, \mathrm{Ma}, \mathrm{Mi}$, and $\mathrm{RP}$ attributes, which was expected due to the volume and frequency of rainfall during both seasons (Figure 1). However, differences were observed between soil management treatments (Table 2). In ExpI, BD and RP were higher, combined with lower Ma values at the $0.05-$ $0.10 \mathrm{~m}$ layer in CT treatment, due to the harrow disking followed by soil leveling after chiseling. This tillage operation with heavy machinery might have affected the attributes in topsoil layers. In SCT, conversely, even using the same operations as in $\mathrm{CT}$, the raised-seedbed construction somehow loosened the soil to levels that led to lower BD and RP values.

An increase in $\mathrm{BD}$ and $\mathrm{RP}$ and a decrease in $\mathrm{TP}$ and Ma were observed from the first (ExpI) to the second (ExpII) crop growing season, for all treatments. These results are explained by the soil chiseling performed before installing ExpI, followed by consecutive two years of experiments in the same field. The intense tillage before installing ExpI resulted in a higher soil disintegration, which seems to have facilitated the uppermost soil layer compaction by machine traffic, as well as the natural rearrangement of the soil particles after chiseling because an increase in the soil strengthening was observed in the second growing season (ExpII).

The topsoil is usually denser than subsoil layers (Colombi et al., 2018) due to intense machinery activities on the soil surface (Kirnak et al., 2016). Besides, the differences in $\mathrm{BD}$ and RP from one growing season to another may have been influenced by the time scale when these soil properties were evaluated in ExpII, whose analysis was carried out after harvesting. In contrast, for ExpI, the physical properties were evaluated 60 days after sowing.

The short-term effects of conventional tillage on soil decompression were also verified by Silva et al. (2012). The soil decompression might be attributed to greater homogeneity in the soil structure after the soil was mechanically chisele, as reported by Calonego et al. (2017), or by climate conditions and cropping systems (Nunes et al., 2015), which explains the lower BD values in ExpI. Fluctuations in soil penetration resistance can occur even during a crop growing season because soil attributes, such as BD and soil porosity, are strongly affected by soil moisture, therefore, related to precipitation, irrigation, and evapotranspiration (Colombi et al., 2018).

$\mathrm{BD}$ and Ma values for the 0.0-0.2 soil layer in ExpI averaged $1.50 \mathrm{Mg} \mathrm{m}^{-3}$ and $0.11 \mathrm{~m}^{3} \mathrm{~m}^{-3}$, respectively, and $1.68 \mathrm{Mg} \mathrm{m}^{-3}$ and $0.07 \mathrm{~m}^{3} \mathrm{~m}^{-3}$ in ExpII. In ExpII, BD and Ma values were similar to those found in the soil profile characterized before soil chiseling $\left(B D=1.63 \mathrm{Mg} \mathrm{m}^{-3}\right.$; $\left.\mathrm{Ma}=0.07 \mathrm{~m}^{3} \mathrm{~m}^{-3}\right)$. Although close to the critical BD values proposed by Reichert et al. (2009), for this range of soil textures $\left(1.69 \mathrm{Mg} \mathrm{m}^{-3}\right)$, high $\mathrm{BD}$ values do not indicate excessive restriction to root growth. These high $\mathrm{BD}$ values can be partially explained by the low clay content in this layer $\left(191.5 \mathrm{~g} \mathrm{~kg}^{-1}\right)$, which already has a higher $\mathrm{BD}$ in natural conditions (Marcolin and Klein, 2011).

The total rainfall from sowing to maturity of soybean was 7,230 and $7,740 \mathrm{~m}^{3}$, for ExpI and ExpII, respectively. Although it was higher in ExpII, the distribution along the season was uneven. In ExpI, the best rainfall distribution resulted in only four supplementary irrigations, totaling $480 \mathrm{~m}^{3} \mathrm{ha}^{-1}$ of supplementary irrigation when the sprinkler system was used and 1,200 $\mathrm{m}^{3} \mathrm{ha}^{-1}$ for surface. In ExpII, 18 and 12 irrigations were performed, totaling 1,970 and 3,600 $\mathrm{m}^{3} \mathrm{ha}^{-1}$, for sprinkler and surface, respectively (Figures 1 and 2).

Concerning the soil management, greater differences in $\theta$ (soil water content) were observed in the rainfed treatment, where NT had lower $\theta$ than CT. After applying the irrigation on the strip border, $\theta$ increased to soil saturation, decreasing the soil aeration space to near zero (Figure 3). A long period with soil aeration below $0.10 \mathrm{~m}^{3} \mathrm{~m}^{-3}$ was observed in the CT treatment after irrigation or rainfall events, indicated as water excess stress for soybean plants. For this same soil class (CT), Olibone et al., 2010; Beutler et al. (2014) verified that soil water excess decreased the soybean grain yield up to $41 \%$.

For the treatment with the sprinkler system, irrigations were more frequent and at depths ranging from 8-16 mm, maintaining $\theta$ to meet the crop water requirements, which results in better soil aeration. A sustainable irrigation system and soil management practices are required to successfully implement soybean in wetlands (Bueno et al., 2020) and provide irrigation and satisfactory drainage.

In this study, NT and SNT showed greater soil aeration in comparison to $\mathrm{CT}$ and SCT, probably due to better soil aggregation provided by no-tillage (Micucci and Taboada, 2006). Moreover, the biopores provided by the winter cover crops (black oats) favored soil aggregation (Six et al., 2004). These factors improved the soil water infiltration rate, as observed by Bonetti et al. (2019) in soil cultivated with grasses and by Ram et al. (2013) in a notillage system with straw on the soil surface.

Better root distribution and elongation were observed at the soil depth 0.0-0.3 $\mathrm{m}$ for CT and NT 
Table 2 - Bulk density, total porosity, macroporosity, microporosity and soil resistance penetration in the 0.0-0.05, 0.05-0.10 and 0.10-0.20 m depth layers, for irrigation treatments and soil management in Expl and Expll.

\begin{tabular}{|c|c|c|c|c|c|c|c|c|c|}
\hline \multirow{2}{*}{ Layer } & \multicolumn{3}{|c|}{ Irrigation } & \multicolumn{4}{|c|}{ Soil management } & \multirow{2}{*}{ Average } & \multirow{2}{*}{ CV } \\
\hline & Sprinkler & Surface & Rainfed & CT & NT & SCT & SNT & & \\
\hline $\mathrm{m}$ & & & & & & & & & $\%$ \\
\hline \multicolumn{10}{|c|}{ Expl } \\
\hline \multicolumn{10}{|c|}{ Bulk density (Mg m²) } \\
\hline $0.00-0.05$ & $1.36^{\mathrm{ns}}$ & 1.36 & 1.38 & $1.4^{\mathrm{ns}}$ & 1.35 & 1.37 & 1.33 & 1.36 & 4.9 \\
\hline $0.05-0.10$ & $1.50^{\text {ns }}$ & 1.49 & 1.51 & $1.56 a^{1}$ & $1.48 b$ & $1.49 \mathrm{~b}$ & $1.47 \mathrm{~b}$ & 1.50 & 4.8 \\
\hline $0.10-0.20$ & $1.65^{\text {ns }}$ & 1.64 & 1.61 & $1.66 a b$ & $1.62 \mathrm{ab}$ & $1.67 \mathrm{a}$ & $1.58 \mathrm{~b}$ & 1.63 & 5.0 \\
\hline \multicolumn{10}{|c|}{ Total porosity $\left(\mathrm{m}^{3} \mathrm{~m}^{-3}\right)$} \\
\hline $0.00-0.05$ & $0.48^{\text {ns }}$ & 0.48 & 0.46 & $0.46^{\text {ns }}$ & 0.48 & 0.47 & 0.49 & 0.47 & 5.4 \\
\hline $0.05-0.10$ & $0.42^{\mathrm{ns}}$ & 0.43 & 0.42 & $0.40 \mathrm{~b}$ & $0.44 a$ & $0.43 a b$ & $0.43 a$ & 0.42 & 7.3 \\
\hline $0.10-0.20$ & $0.36^{\text {ns }}$ & 0.37 & 0.38 & $0.37 a b$ & $0.37 a b$ & $0.35 b$ & $0.39 \mathrm{a}$ & 0.37 & 7.4 \\
\hline \multicolumn{10}{|c|}{ Macroporosity $\left(\mathrm{m}^{3} \mathrm{~m}^{-3}\right)$} \\
\hline $0.00-0.05$ & $0.20^{\text {ns }}$ & 0.19 & 0.17 & $0.16 b$ & $0.19 a b$ & $0.18 a b$ & $0.22 \mathrm{a}$ & 0.19 & 21.8 \\
\hline $0.05-0.10$ & $0.12^{\mathrm{ns}}$ & 0.14 & 0.14 & $0.10 \mathrm{c}$ & $0.16 a$ & $0.13 b$ & $0.15 a$ & 0.13 & 22.6 \\
\hline $0.10-0.20$ & $0.08^{\text {ns }}$ & 0.08 & 0.07 & $0.07 \mathrm{ab}$ & $0.08 a$ & $0.06 \mathrm{~b}$ & $0.08 \mathrm{a}$ & 0.07 & 17.3 \\
\hline \multicolumn{10}{|c|}{ Microporosity $\left(\mathrm{m}^{3} \mathrm{~m}^{-3}\right)$} \\
\hline $0.00-0.05$ & $0.28^{\text {ns }}$ & 0.28 & 0.29 & $0.29^{\text {ns }}$ & 0.28 & 0.29 & 0.28 & 0.29 & 4.1 \\
\hline $0.05-0.10$ & $0.30^{\text {ns }}$ & 0.29 & 0.29 & $0.29 a b$ & $0.28 b$ & $0.30 \mathrm{a}$ & $0.29 b$ & 0.29 & 5.1 \\
\hline $0.10-0.20$ & $0.29^{\text {ns }}$ & 0.28 & 0.29 & $0.28^{\text {ns }}$ & 0.29 & 0.29 & 0.29 & 0.29 & 4.7 \\
\hline \multicolumn{10}{|c|}{ Soil resistance penetration (MPa) } \\
\hline $0.00-0.05$ & $1.12^{\text {ns }}$ & 1.37 & 1.28 & $1.57 a^{2}$ & $1.46 \mathrm{~b}$ & $1.02 \mathrm{bc}$ & $0.95 \mathrm{c}$ & 1.25 & 26.6 \\
\hline $0.05-0.10$ & $1.86^{\text {ns }}$ & 1.80 & 1.79 & $2.52 \mathrm{a}$ & $1.81 \mathrm{~b}$ & $1.62 \mathrm{~b}$ & $1.32 \mathrm{~b}$ & 1.82 & 29.6 \\
\hline $0.10-0.20$ & $2.88^{\text {ns }}$ & 2.46 & 2.98 & $2.66 a b$ & $2.54 \mathrm{~b}$ & $3.16 \mathrm{a}$ & $2.72 a b$ & 2.77 & 18.5 \\
\hline \multicolumn{10}{|c|}{ Expll } \\
\hline \multicolumn{10}{|c|}{ Bulk density (Mg m $\left.\mathrm{m}^{-3}\right)$} \\
\hline $0.00-0.05$ & $1.50^{\text {ns }}$ & 1.51 & 1.53 & $1.51^{\mathrm{ns}}$ & 1.51 & 1.51 & 1.52 & 1.51 & 3.7 \\
\hline $0.05-0.10$ & $1.70^{\text {ns }}$ & 1.68 & 1.68 & $1.72^{\mathrm{ns}}$ & 1.66 & 1.71 & 1.66 & 1.69 & 6.2 \\
\hline $0.10-0.20$ & $1.77^{\mathrm{ns}}$ & 1.75 & 1.75 & $1.77 \mathrm{ab}$ & $1.75 a b$ & $1.79 \mathrm{a}$ & $1.73 \mathrm{~b}$ & 1.76 & 2.1 \\
\hline \multicolumn{10}{|c|}{ Total porosity $\left(\mathrm{m}^{3} \mathrm{~m}^{-3}\right)$} \\
\hline $0.00-0.05$ & $0.42^{\text {ns }}$ & 0.42 & 0.41 & $0.42^{\mathrm{ns}}$ & 0.42 & 0.42 & 0.41 & 0.42 & 5.2 \\
\hline $0.05-0.10$ & $0.34^{\text {ns }}$ & 0.35 & 0.35 & $0.34^{\text {ns }}$ & 0.36 & 0.34 & 0.36 & 0.35 & 11.5 \\
\hline $0.10-0.20$ & $0.31^{\mathrm{ns}}$ & 0.32 & 0.32 & $0.32 a b$ & $0.33 a b$ & $0.31 \mathrm{~b}$ & $0.33 a$ & 0.32 & 4.5 \\
\hline \multicolumn{10}{|c|}{ Macroporosity $\left(\mathrm{m}^{3} \mathrm{~m}^{-3}\right)$} \\
\hline $0.00-0.05$ & $0.12^{\text {ns }}$ & 0.13 & 0.12 & $0.13^{\text {ns }}$ & 0.12 & 0.13 & 0.12 & 0.12 & 17.3 \\
\hline $0.05-0.10$ & $0.04^{\mathrm{ns}}$ & 0.05 & 0.06 & $0.04^{\mathrm{ns}}$ & 0.06 & 0.04 & 0.06 & 0.05 & 61.2 \\
\hline $0.10-0.20$ & $0.03^{\text {ns }}$ & 0.04 & 0.04 & $0.03^{\text {ns }}$ & 0.04 & 0.02 & 0.04 & 0.03 & 49.0 \\
\hline \multicolumn{10}{|c|}{ Microporosity $\left(\mathrm{m}^{3} \mathrm{~m}^{-3}\right)$} \\
\hline $0.00-0.05$ & $0.30^{\text {ns }}$ & 0.29 & 0.28 & $0.28^{\text {ns }}$ & 0.29 & 0.29 & 0.29 & 0.29 & 5.6 \\
\hline $0.05-0.10$ & $0.30^{\text {ns }}$ & 0.30 & 0.29 & $0.29^{\text {ns }}$ & 0.30 & 0.29 & 0.30 & 0.30 & 5.4 \\
\hline $0.10-0.20$ & $0.28^{\text {ns }}$ & 0.29 & 0.28 & $0.28^{\text {ns }}$ & 0.28 & 0.28 & 0.29 & 0.28 & 7.1 \\
\hline \multicolumn{10}{|c|}{ Soil resistance penetration (MPa) } \\
\hline $0.00-0.05$ & $2.09^{\text {ns }}$ & 2.18 & 2.26 & $2.23^{\mathrm{ns}}$ & 2.06 & 2.35 & 2.07 & 2.18 & 23.8 \\
\hline $0.05-0.10$ & $3.93^{\text {ns }}$ & 3.29 & 3.95 & $4.76 \mathrm{a}$ & 3.02 bc & $4.42 a b$ & $2.69 c$ & 3.72 & 28.8 \\
\hline $0.10-0.20$ & $5.24^{\text {ns }}$ & 4.84 & 4.58 & $5.58 \mathrm{a}$ & $3.88 b$ & $5.57 \mathrm{a}$ & $4.50 \mathrm{ab}$ & 4.88 & 19.3 \\
\hline
\end{tabular}

${ }^{1}$ Averages followed by the same letter in the lines, for irrigation or soil management, did not differ by the Tukey test $(p<0.05)$; nsnot significant $(p>0.05)$; CT = Conventional tillage; NT = no-tillage; SCT = conventional tillage with raised-seedbed and SNT = no-tillage tillage with raised-seedbed.

(Figure 4) for the rainfed treatment in ExpII, probably due to lower water availability to plants in the topsoil. This increasing root growth in rainfed conditions was stimulated by water depletion in the upper soil layer, forcing roots to grow deeper searching for water and exploring a greater volume of soil (Kunert et al., 2016). However, root distribution showed little difference between the soil management treatments, indicating that soil compaction was not restrictive to root growth, as observed by Moraes et al. (2020).

As the soils become dry, mechanical impedance might reduce root growth and development; however, our study demonstrated that combining the plant root phenotyping quantifications and soil characteristics 

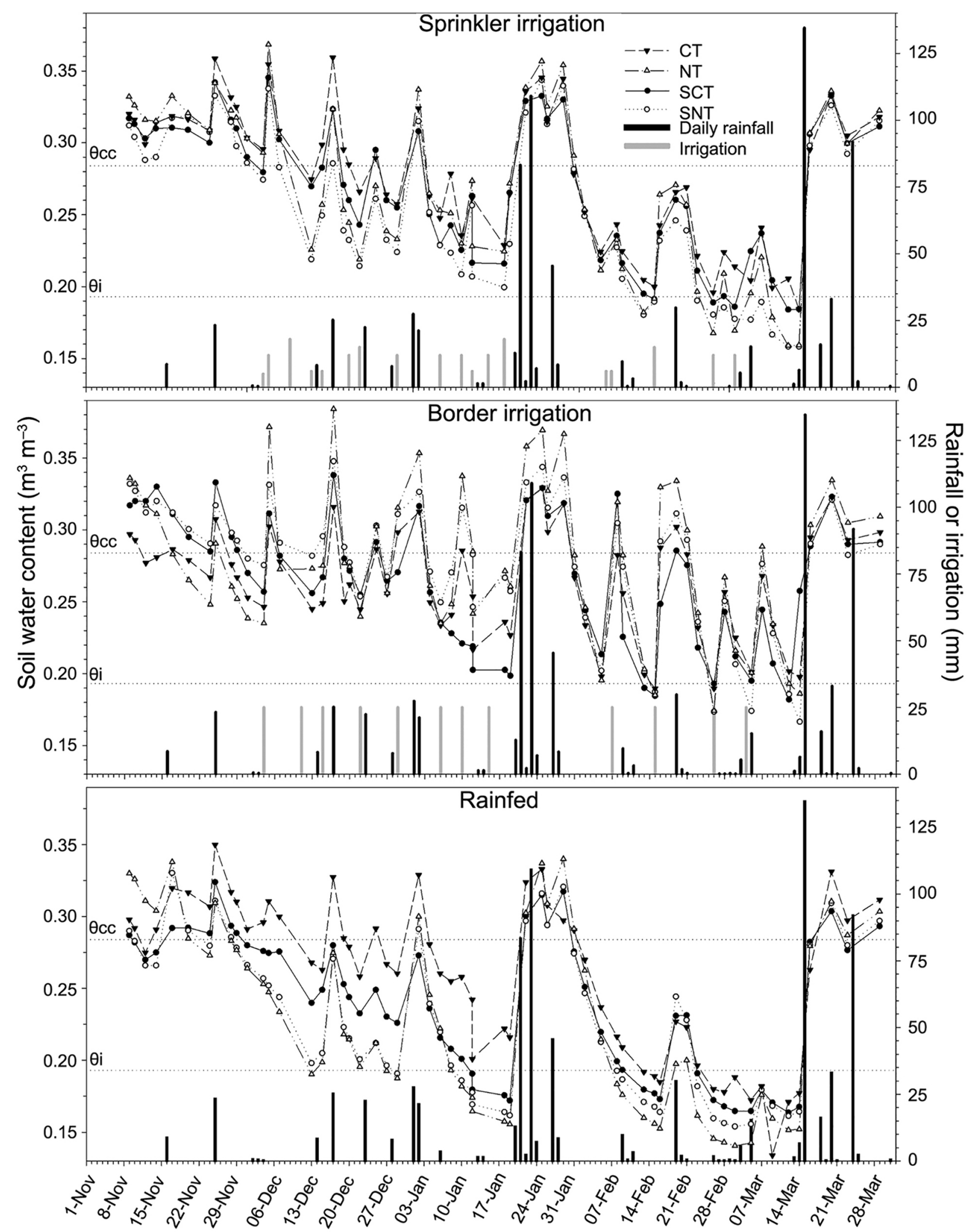

Figure 2 - Soil water content (0.0-0.25 m), rainfall, and irrigations by sprinkler, surface, and rainfed in Expll; CT = Conventional tillage; NT = no-tillage; SCT = conventional tillage with raised-seedbed; and SNT = no-tillage with raised-seedbed; $\theta c c$ = Soil water content at field capacity; $\theta \mathrm{i}=$ Soil water content at $50 \%$ of the total available water (TAW), used in the irrigations. 


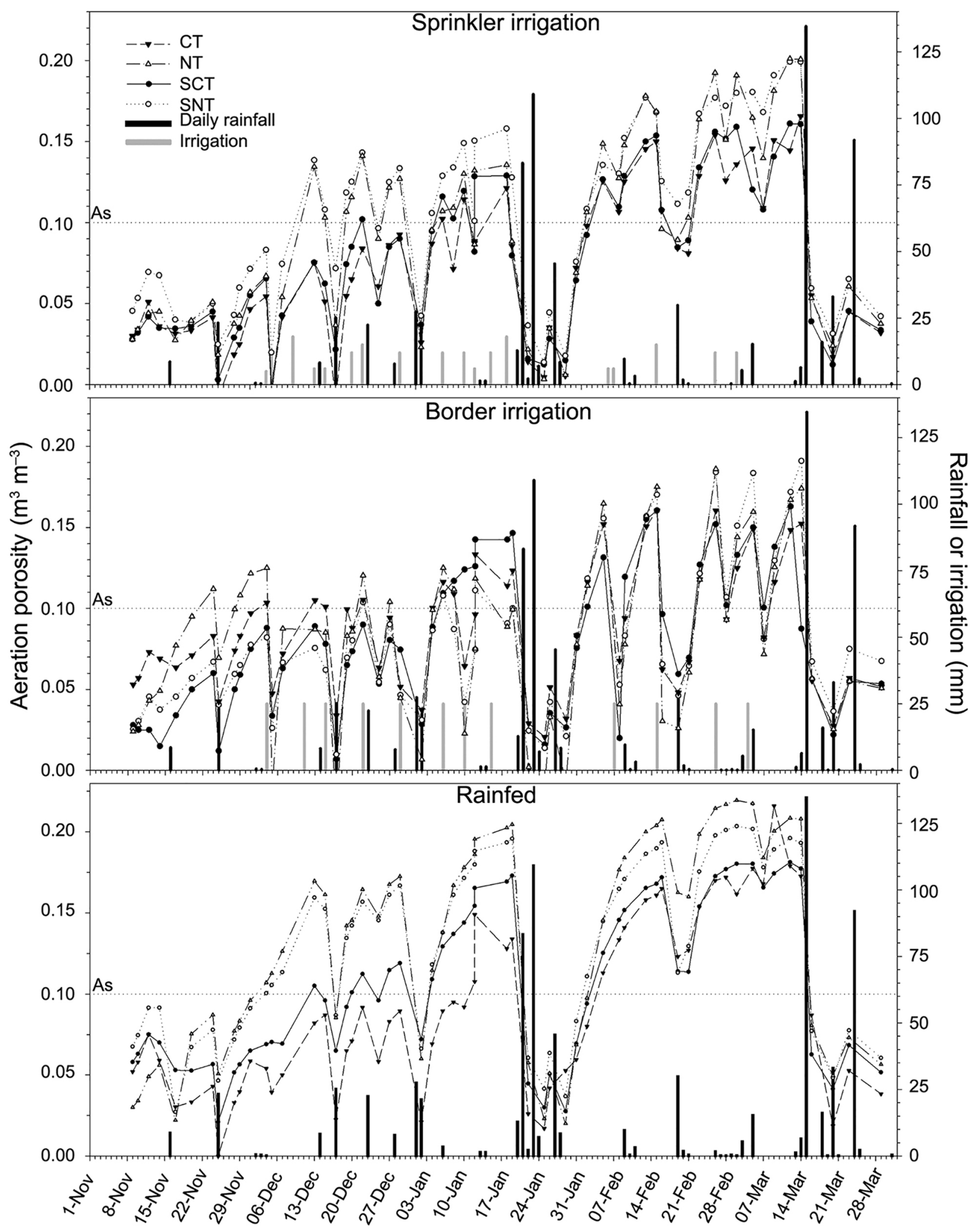

Figure 3 - Soil aeration space, rainfall, and irrigations by sprinkler, surface, and rainfed in the Expll. CT = Conventional tillage; NT = no-tillage; $\mathrm{SCT}=$ conventional tillage with raised-seedbed; and SNT = no-tillage tillage with raised-seedbed; As = Soil aeration space of $10 \%$. 
Conventional tillage

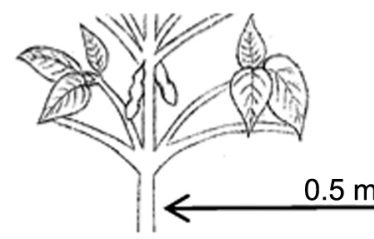

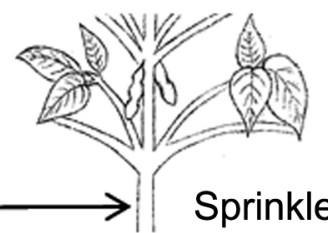

Sprinkler irrigation

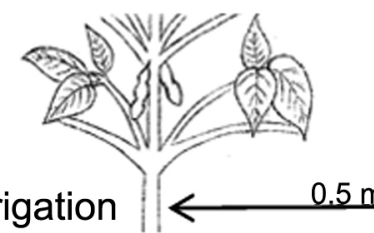

$0.5 \mathrm{~m}$
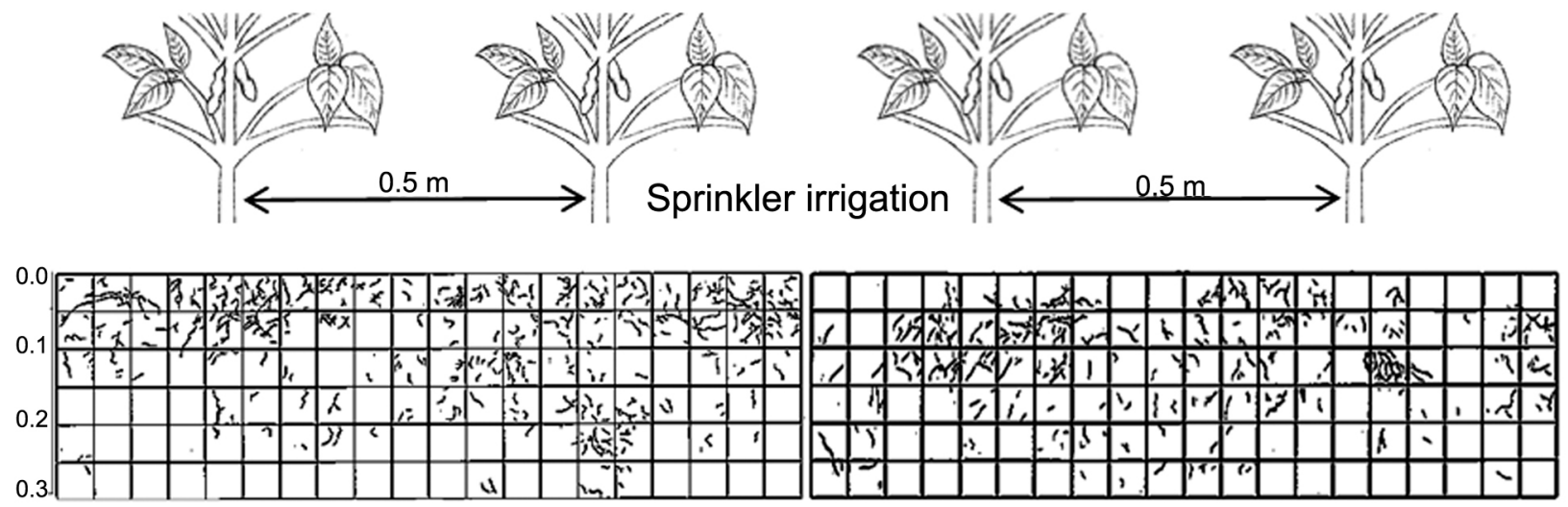

Surface irrigation

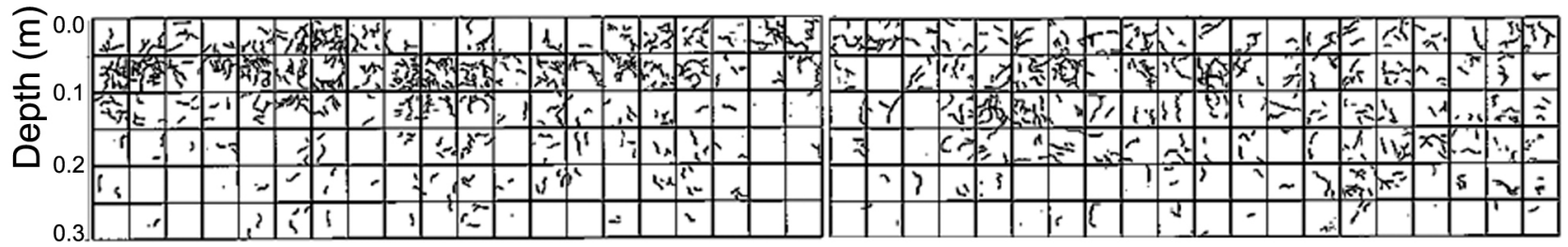

Rainfed

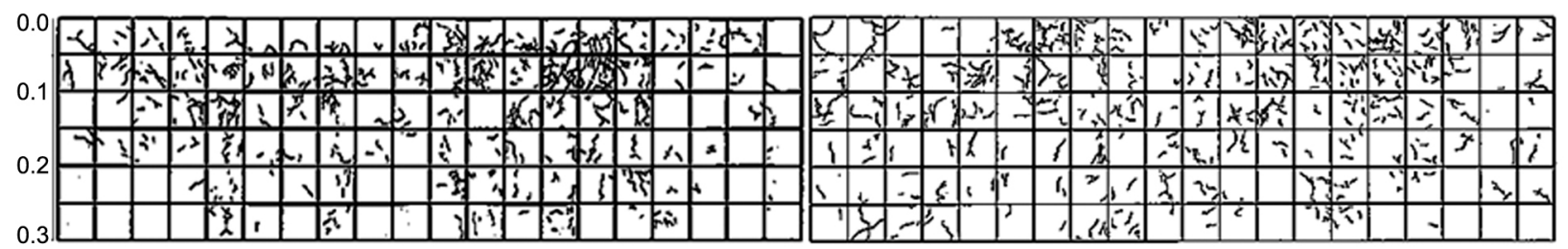

Figure 4 - Root system distribution of soybean crop for conventional tillage, no-tillage, irrigated by sprinkler, surface and rainfed at the R5 development stage (Expll).

improve the understanding of how the processes below the soil surface can affect soybean yield, as an alternative to crop rotation in wetlands.

In ExpII, the numbers of nodules per soybean plant did not show an interaction between factors, being lower in the CT treatment with no significant differences between the irrigation types (Table 3). However, there was a significant interaction between the nodule dry matter, which was higher in SNT in rainfed conditions. As expected, the non-irrigated CT and sprinkler irrigated CT had the lowest nodule dry matter. These results indicated that a lower nodulation is related to lower water availability (Kunert et al., 2016), as it occurred in these treatments.

In ExpII, no interaction between the factors was observed for plant height and pods per plant (Table 3). Plant height was lower in the CT and SCT treatments by approximately $0.3 \mathrm{~m}$ compared to NT and SNT. In the rainfed treatments, plants were shorter with a smaller number of pods per plant compared to irrigated treatments, due to the water deficit caused by a poor rainfall distribution, also verified by Bellaloui et al. (2013).

Soybean grain yield showed statistical interaction between irrigation treatments and soil management (Table 4). The CT sprinkler irrigation had grain yield equal to the rainfed. However, the CT surface (strip border) irrigated showed a greater yield in ExpI and ExpII. These results can be related to a smaller water availability to plant due to lower infiltration at the layer $0.050 .10 \mathrm{~m}$, attributed to greater BD and compaction in the CT treatment possibly related to plowing pans resulting from tillage. Consequently, more water losses by runoff and soil water evaporation were observed, greater in sprinkler irrigation than in surface irrigation, because adjusting the sprinkler flow rate to infiltration capacity is a difficult task.

The NT, SCT, and SNT presented a greater grain yield $(32,25$, and $12 \%$ higher) than the CT sprinkler irrigation, which might be related to lower soil 
Table 3 - Number and dry matter of nodules per plant, plant height, number of pods per plant and shoot dry matter of soybean crop under different irrigation treatments and soil management in Expll.

\begin{tabular}{|c|c|c|c|c|c|c|}
\hline \multirow{2}{*}{$\begin{array}{l}\text { Irrigation } \\
\text { treatments }^{1}\end{array}$} & \multicolumn{4}{|c|}{ Soil management } & \multirow{2}{*}{ Average } & \multirow{2}{*}{ CV } \\
\hline & Conventional tillage & No-tillage & Conventional tillage with raised-seedbed & No-tillage with raised-seedbed & & \\
\hline & & & & & & $\%$ \\
\hline \multicolumn{7}{|c|}{ Number of nodules per plant } \\
\hline Sprinkler & 83.44 & 118.67 & 112.89 & 115.67 & $107.67^{\text {ns }}$ & \multirow{3}{*}{20.3} \\
\hline Surface & 76.33 & 117.44 & 107.11 & 101.78 & 100.67 & \\
\hline Rainfed & 71.44 & 72.78 & 109.67 & 106.22 & 90.03 & \\
\hline Average & $77.07 \mathrm{~b}$ & $102.96 \mathrm{a}$ & $109.89 \mathrm{a}$ & $107.89 \mathrm{a}$ & 99.46 & \\
\hline \multicolumn{7}{|c|}{ Nodules dry matter (g) } \\
\hline Sprinkler & $0.35 \mathrm{abB}$ & $0.49 \mathrm{aAB}$ & $0.59 \mathrm{aA}$ & $0.56 \mathrm{~A}$ & 0.53 & \multirow{3}{*}{14.8} \\
\hline Surface & $0.40 \mathrm{aB}$ & $0.58 \mathrm{aA}$ & $0.51 \mathrm{abAB}$ & $0.55 \mathrm{AB}$ & 0.48 & \\
\hline Rainfed & $0.25 \mathrm{bC}$ & $0.33 \mathrm{bBC}$ & $0.44 \mathrm{bAB}$ & $0.52 \mathrm{~A}$ & 0.38 & \\
\hline Average & 0.33 & 0.47 & 0.51 & 0.54 & 0.46 & \\
\hline \multicolumn{7}{|c|}{ Plant height (cm) } \\
\hline Sprinkler & 109.90 & 141.03 & 115.45 & 142.03 & $127.10 \mathrm{a}$ & \multirow{3}{*}{10.7} \\
\hline Surface & 102.30 & 151.35 & 110.70 & 146.26 & $127.65 \mathrm{a}$ & \\
\hline Rainfed & 85.37 & 111.95 & 88.19 & 105.46 & $97.74 \mathrm{~b}$ & \\
\hline Average & $99.19 b$ & $134.77 \mathrm{a}$ & $104.78 b$ & $131.25 \mathrm{a}$ & 117.50 & \\
\hline \multicolumn{7}{|c|}{ Pods per plant $\left(n^{\circ}\right)$} \\
\hline Sprinkler & 61.16 & 80.29 & 72.92 & 67.14 & $70.38 \mathrm{ab}$ & \multirow{3}{*}{5.9} \\
\hline Surface & 73.60 & 71.39 & 67.85 & 78.46 & $72.82 \mathrm{a}$ & \\
\hline Rainfed & 53.30 & 65.92 & 64.69 & 54.80 & $59.68 b$ & \\
\hline Average & $62.68^{\text {ns }}$ & 72.53 & 68.49 & 66.80 & 67.63 & \\
\hline \multicolumn{7}{|c|}{ Shot dry matter (Mg ha-1) } \\
\hline Sprinkler & 9.76 & 11.89 & 11.45 & 12.10 & $11.30 \mathrm{a}$ & \multirow{3}{*}{3.6} \\
\hline Surface & 9.40 & 11.41 & 10.69 & 11.51 & $10.75 \mathrm{a}$ & \\
\hline Rainfed & 6.06 & 7.71 & 7.98 & 8.34 & $7.52 b$ & \\
\hline Average & $8.41 \mathrm{~b}$ & $10.34 \mathrm{a}$ & $10.04 \mathrm{a}$ & $10.65 a$ & 9.86 & \\
\hline
\end{tabular}

compaction observed in the layer 0.05-0.10 m. This result demonstrates the negative impact of soil compaction in $\mathrm{CT}$ treatment, understanding that $\mathrm{BD}, \mathrm{RP}, \mathrm{Mi}$, and Ma greatly influence grain yield between many soil physical attributes (Moraes et al., 2020). A lower water infiltration rate is a limiting factor for sprinkler irrigation in lowlands (Bonetti et al., 2019). Thus, before installing a sprinkler irrigation system (center and lateral-move pivots, solid set sprinkler), the soil physical properties need to be evaluated.

ExpII showed a greater water deficit was observed and NT, SCT and SNT did not show differences for grain yield when irrigated. However, grain yield in these treatments were $29 \%$ greater compared to those in rainfed conditions. In ExpI, there was no difference between irrigated and rainfed treatments. These results emphasize the importance of using supplementary irrigation in years with greater water deficit, as in ExpII.

The thousand-grain weight was equal for all treatments in ExpI, while in ExpII, it was lower in the rainfed treatments, resulting in lower grain yield. This variable was reduced mainly by the crop conditions during the grain filling stage (R5-R6) (Bonetti et al.,
2019). Seed number and individual seed mass are the major components to determine soybean yield (Van Roekel et al., 2015). Therefore, rain distribution was satisfactory in ExpI and unsatisfactory in ExpII, especially in reproductive stages with higher crop water requirements, factors that explain the lower grain weight in rainfed conditions of ExpII.

Water productivity was lower in CT than in NT (ExpI), similar to total water, but with lower grain yield. For ExpI and ExpII, the water productivity average was 0.51 and $0.47 \mathrm{~kg} \mathrm{~m}^{-3}$, respectively. In ExpI, irrigated water productivity showed better response for the sprinkler system, with a $\mathrm{WP}_{\mathrm{IR}}$ of about $7.92 \mathrm{~kg} \mathrm{~m}^{-3}$, $140 \%$ greater than the treatment with surface irrigation $\left(3.29 \mathrm{~kg} \mathrm{~m}^{-3}\right)$. In ExpII, irrigated water productivity was equally greater in the sprinkler than in surface irrigation for all the soil management treatments.

Total shoot dry matter was greater for the irrigated treatments and lower in the CT soil management. Despite greater shoot dry matter, the harvest index was still similar for all treatments, due to the greater grain yield in the same treatments. Soybean grain yield is a function of shoot dry matter accumulation during 
Table 4 - Grain yield, a thousand-grain weight, water productivity and irrigated water productivity in both Expl and Expll, and harvest index in the Expll, for soybean crop, under different irrigation treatments and soil management.

\begin{tabular}{|c|c|c|c|c|c|c|}
\hline \multirow{2}{*}{$\begin{array}{l}\text { Irrigation } \\
\text { treatments }^{1}\end{array}$} & \multicolumn{4}{|c|}{ Soil management } & \multirow{2}{*}{ Average } & \multirow{2}{*}{ CV } \\
\hline & Conventional tillage & No-tillage & Conventional Tillage with raised-seedbed & No-tillage with raised-seedbed & & \\
\hline & & & & & & $\%$ \\
\hline \multicolumn{7}{|c|}{ Expl } \\
\hline \multicolumn{7}{|c|}{ Grain yield $\left(\mathrm{Mg} \mathrm{ha}^{-1}\right)$} \\
\hline Sprinkler & $3.64 a b^{2}$ & $4.11^{\mathrm{ns}}$ & $3.77^{\mathrm{ns}}$ & $3.67^{\text {ns }}$ & 3.78 & \multirow{3}{*}{9.5} \\
\hline Surface & $4.01 \mathrm{a}$ & 4.15 & 3.85 & 3.76 & 3.94 & \\
\hline Rainfed & $3.15 b$ & 3.77 & 3.60 & 3.74 & 3.57 & \\
\hline Average & 3.60 & 4.01 & 3.71 & 3.72 & 3.76 & \\
\hline \multicolumn{7}{|c|}{ A thousand-grain weight (g) } \\
\hline Sprinkler & 179.03 & 182.43 & 176.68 & 178.59 & $179.18^{\text {ns }}$ & \multirow{3}{*}{7.4} \\
\hline Surface & 176.24 & 188.42 & 186.50 & 177.47 & 182.16 & \\
\hline Rainfed & 165.63 & 197.84 & 184.06 & 189.49 & 184.25 & \\
\hline Average & $173.63^{\text {ns }}$ & 189.57 & 182.41 & 181.85 & 181.86 & \\
\hline \multicolumn{7}{|c|}{ Water productivity $\left(\mathrm{kg} \mathrm{m}^{-3}\right)$} \\
\hline Sprinkler & $4.03 \mathrm{bB}$ & $5.31 \mathrm{aA}$ & $5.03 \mathrm{aA}$ & $4.56 \mathrm{aA}$ & 4.73 & \multirow{3}{*}{9.0} \\
\hline Surface & $5.09 \mathrm{a}$ & $4.93 \mathrm{a}$ & 5.17 a & $5.07 \mathrm{a}$ & 5.07 & \\
\hline Rainfed & $3.37 \mathrm{bB}$ & $4.04 \mathrm{bA}$ & $3.42 \mathrm{bAB}$ & $3.54 \mathrm{bAB}$ & 3.59 & \\
\hline Average & 4.16 & 4.76 & 4.54 & 4.39 & 4.46 & \\
\hline \multicolumn{7}{|c|}{ Irrigated water productivity $\left(\mathrm{kg} \mathrm{m}^{-3}\right)$} \\
\hline Sprinkler & 7.58 & 8.57 & 7.87 & 7.64 & $7.92 \mathrm{a}$ & \multirow{2}{*}{6.0} \\
\hline Surface & 3.34 & 3.46 & 3.21 & 3.13 & $3.29 \mathrm{~b}$ & \\
\hline Average & $5.46 \mathrm{~b}$ & $6.02 \mathrm{a}$ & $5.54 \mathrm{ab}$ & $5.39 \mathrm{~b}$ & 5.61 & \\
\hline \multicolumn{7}{|c|}{ Expll } \\
\hline \multicolumn{7}{|c|}{ Grain yield $\left(\mathrm{Mg} \mathrm{ha}^{-1}\right)$} \\
\hline Sprinkler & $4.03 \mathrm{bB}$ & $5.31 \mathrm{aA}$ & $5.03 \mathrm{aA}$ & $4.56 \mathrm{aA}$ & 4.73 & \multirow{3}{*}{9.0} \\
\hline Surface & $5.09 a$ & $4.93 \mathrm{a}$ & 5.17 a & $5.07 a$ & 5.07 & \\
\hline Rainfed & $3.37 \mathrm{bB}$ & $4.04 \mathrm{bA}$ & $3.42 \mathrm{bAB}$ & $3.54 \mathrm{bAB}$ & 3.59 & \\
\hline Average & 4.16 & 4.76 & 4.54 & 4.39 & 4.46 & \\
\hline \multicolumn{7}{|c|}{ A thousand-grain weight (g) } \\
\hline Sprinkler & 170.04 & 177.30 & 176.48 & 171.68 & $173.87 b$ & \multirow{3}{*}{2.2} \\
\hline Surface & 169.56 & 183.62 & 184.54 & 185.61 & $180.83 a$ & \\
\hline Rainfed & 149.69 & 160.14 & 156.99 & 152.77 & $154.90 \mathrm{C}$ & \\
\hline Average & $163.10 \mathrm{~b}$ & $173.69 \mathrm{a}$ & $172.67 \mathrm{a}$ & $170.02 \mathrm{a}$ & 169.87 & \\
\hline \multicolumn{7}{|c|}{ Water productivity $\left(\mathrm{kg} \mathrm{m}^{-3}\right)$} \\
\hline Sprinkler & 0.41 & 0.51 & 0.52 & 0.51 & $0.49^{\text {ns }}$ & \multirow{3}{*}{9.3} \\
\hline Surface & 0.45 & 0.47 & 0.46 & 0.45 & 0.46 & \\
\hline Rainfed & 0.44 & 0.52 & 0.44 & 0.46 & 0.46 & \\
\hline Average & $0.43 b$ & $0.50 \mathrm{a}$ & $0.47 \mathrm{ab}$ & $0.47 a b$ & 0.47 & \\
\hline \multicolumn{7}{|c|}{ Irrigated water productivity $\left(\mathrm{kg} \mathrm{m}^{-3}\right)$} \\
\hline Sprinkler & $2.04 \mathrm{aB}$ & $2.50 \mathrm{aA}$ & $2.55 \mathrm{aA}$ & $2.52 \mathrm{aA}$ & 2.40 & \multirow{2}{*}{12.8} \\
\hline Surface & $1.41 \mathrm{~b}$ & $1.48 \mathrm{~b}$ & $1.44 \mathrm{~b}$ & $1.41 \mathrm{~b}$ & 1.43 & \\
\hline Average & 1.72 & 1.99 & 1.99 & 1.96 & 1.91 & \\
\hline & & & Harvest index $\left(\mathrm{kg} \mathrm{m}^{-3}\right)$ & & & \\
\hline Sprinkler & 0.41 & 0.41 & 0.44 & 0.41 & $0.42^{\text {ns }}$ & \\
\hline Surface & 0.54 & 0.48 & 0.49 & 0.45 & 0.49 & 19.7 \\
\hline Rainfed & 0.56 & 0.54 & 0.43 & 0.44 & 0.49 & \\
\hline Average & $0.50^{\text {ns }}$ & 0.48 & 0.46 & 0.43 & 0.47 & \\
\hline
\end{tabular}

the crop growth and the harvest index is an inherited characteristic of each cultivar, sowing date, and plant density (Steduto et al., 2009).

Soybean cultivation with raised-seedbeds can be a sustainable alternative for years with greater rainfall or high irrigation requirement by enabling better control of the time and irrigation depths applied, while providing rapid drainage. Hence, the periods with low soil aeration are fewer (Gubiani et al., 2018). On the other hand, the soybean cultivation in NT 
shows less risk, limiting stresses induced by water deficit or excess in this environment and improving water availability in the soil (Olibone et al., 2010) and root development (Williams and Weil, 2004).

Irrigation can minimize the low soil physical quality and obtain greater soybean grain yield. Sprinkler irrigation results in higher soybean grain yield with less water use, showing the potential of integrating this irrigation system to have sustainability in adopting crop rotations in lowlands in southern Brazil, particularly for water savings approaches. Additionally, the use of a central pivot reduces the need for labor and soil preparation. According to AlKaisi et al. (2016), crop rotation has a higher economic return than single cropping over the years.

Despite the positive implications in using alternative crops to irrigated rice in lowlands, creating conditions that support the use of other cropping systems in these soils, is more than to remove the inherent difficulties presented by the soils in lowlands. Although much of the irrigation structure is already used for irrigated rice in these areas, farmers should consider their investment capacity to bear the costs of soil correction and the installation of irrigation systems to avoid the risk of soil water deficit for the alternative system.

Capitalized farmers can afford investments in more complex systems, such as central pivots, which have a high initial cost but require less energy, labor besides presenting a much more uniform water application. Therefore, adopting other cropping systems, such as conservationist practices, involves technical, cultural, and economic difficulties that need to be overcome. Some practices involve the adoption of agriculture aimed at a long-term production system, not only for the next season but also for the implementation of the no-tillage system, identifying the physical and chemical improvements to be adopted and not in a simplified way only with the absence of soil tillage.

\section{Conclusions}

Adopting a soybean-rice crop rotation system associated with no-tillage and sprinkler or furrow irrigation in substitution of continuously flooded rice brings improvements to the sustainability of this agroecosystem. Soil physical limitations represented by a high bulk density and soil penetration resistance at the layer $0.05-0.10 \mathrm{~m}$ in conventional tillage reduces the yield of rainfed soybean compared to notillage. The use of irrigation in lowland soils increases soybean yield by about $36 \%$ in years of uneven rainfall distribution.

The use of sprinkler irrigation for soybean resulted in higher irrigated water productivity $(90$ $\%$ ) compared to surface irrigation, contributing to a sustainable increase of grain yield.

\section{Acknowledgments}

The author thank the Graduate Program in Agricultural Engineering at the Federal University of Santa Maria (Santa Maria, Rio Grande do Sul, Brazil) and the Federal University of Pampa, Campus of Itaqui (Itaqui, Rio Grande do Sul, Brazil) for providing the infrastructure to carry out the experiments.

\section{Authors' Contributions}

Conceptualization: Giacomeli, R.; Carlesso, R.; Petry, M.T.; Beutler, A.N. Design of methodology: Giacomeli, R.; Carlesso, R.; Petry, M.T.; Chechi, L.; Beutler, A.N. Data acquisition: Giacomeli, R.; Chechi, L.; Beutler, A.N.; Fulaneti, F.S.; Ferrazza, C.M. Data analysis: Giacomeli, R.; Petry, M.T.; Chechi, L. Writing and editing: Giacomeli, R.; Carlesso, R.; Petry, M.T.; Chechi, L.; Beutler, A.N.

\section{References}

Al-Kaisi, M.M.; Archontoulis, S.; Kwaw-Mensah, D. 2016. Soybean spatiotemporal yield and economic variability as affected by tillage and crop rotation. Agronomy Journal 108: 1-14.

Allen, R.G.; Pereira, L.S.; Raes, D.; Smith, M. 1998. Crop Evapotranspiration: guidelines for computing crop water requirements. FAO, Rome, Italy. (Irrigation and Drainage Paper, $56)$.

Alvares, C.A.; Stape, J.L.; Sentelhas, P.C.; Gonçalves, J.L.M.; Sparovek, G. 2013. Köppen's climate classification map for Brazil. Meteorologische Zeitschrift 22: 711-728.

Bellaloui, N.; Mengistu, A.; Kassem, M.A. 2013. Effects of genetics and environment on fatty acid stability in soybean seed. Food and Nutrition Sciences 4: 165-175.

Beutler, A.N.; Giacomeli, R.; Alberto, C.M.; Silva, V.N.; Silva, G.F.; Machado, G.A.; Santos, A.T.L. 2014. Soil hydric excess and soybean yield and development in Brazil. Australian Journal of Crop Science 8: 1461-1466.

Bonetti, J.A.; Anghinoni, I.; Gubiani, P.I.; Cecagno, D.; Moraes, M.T. 2019. Impact of a long-term crop-livestock system on the physical and hydraulic properties of an Oxisol. Soil and Tillage Research 186: 280-291.

Bueno, M.V.; Campos, A.D.S.; Silva, J.T.; Massey, J.; Timm, L.C.; Faria, L.C.; Roel, A.; Parfitt, J.M.B. 2020. Improving the drainage and irrigation efficiency of lowland soils: land-forming options for southern Brazil. Journal of Irrigation and Drainage Engineering 146: 1-8.

Calonego, J.C.; Raphael, J.P.A.; Rigon, J.P.G.; Oliveira Neto, L.; Rosolem, C.A. 2017 Soil compaction management and soybean yields with cover crops under no-till and occasional chiseling. European Journal of Agronomy 85: 31-37.

Christiansen, J.E. 1942. Irrigation by Sprinkling. University of California, Berkeley, CA, USA.

Colombi, T.L.C.; Torres, A.; Walter, A.; Keller, T. 2018. Feedbacks between soil penetration resistance, root architecture and water uptake limit water accessibility and crop growth: a vicious circle. Science of the Total Environment 626: 1026-1035. 
Companhia Nacional de Abastecimento [CONAB]. 2020. Brazilian crop production follow-up: grains 2019/2020 season; seventh survey, Mar 2020 = Acompanhamento da Safra Brasileira de Grãos: Safra 2019/20. Available at: https://www.conab.gov.br/ component/k2/item/download/31024_94fd6422a5a9673c1b6df2 Obe2e2f502 [Accessed Apr 13, 2020] (in Portuguese).

Denardin, L.G.O.; Carmona, F.C.; Veloso, M.G.; Martins, A.P.; Freitas, T.F.S.; Carlos, F.S.; Marcolin, É.; Camargo, F.A.O.; Anghinoni, I. 2019. No-tillage increases irrigated rice yield through soil quality improvement along time. Soil and Tillage Research 186: 64-69.

Fehr, W.R.; Caviness, C.E. 1977. Stages of Soybean Development. Iowa State University, Ames, IA, USA (Special Report, 80).

Ferreira, E.B.; Cavalcanti, P.P.; Nogueira, D.A. 2014. ExpDes: an $\mathrm{R}$ package for ANOVA and experimental designs. Applied Mathematics 5: 2952-2958.

Fin, S.S.; Marchesan, E.; Gubiani, P.I.; Farenzena, J.A.P.; Murari, M.S.; Coelho, L.L.; Cargnelutti, A.; Aramburu, B.B. 2018. Duration of the effects of scarification and raised bed associated with vegetation cover on soybean yield on an Alfisol. Pesquisa Agropecuária Brasileira 53: 1230-1238.

Giacomeli, R.; Marchesan, E.; Oliveira, M.L.; Martin, T.; Teló, G.M.; Donato, G.; Silva, M.F. 2017. Physical properties and crop management for corn in an albaqualf. Revista Brasileira de Ciência do Solo 41: 1-14.

Gubiani, P.I.; Müller, E.A.; Somavilla, A.; Zwirtes, A.L.; Mulazzani, R.P.; Marchesan, E. 2018. Transpiration reduction factor and soybean yield in low land soil with ridge and chiseling. Revista Brasileira de Ciência do Solo 42: 1-14.

Kirnak, H.; Gokalp, S.; Dogan, E.; Çopur, O. 2016. Effects of irrigation, soil compaction and fertilization treatments on physiological: vegetative characteristics and root development of soybean. Legume Research 39: 52-60.

Kunert, K.J.; Vorster, B.J.; Fenta, B.A.; Kibido, T.; Dionisio, G.; Foyer, C.H. 2016. Drought stress responses in soybean roots and nodules. Frontiers in Plant Science 7: 1-7.

Marcolin, C.D.; Klein, V.A. 2011. Determination of relative soil density through a pedotransfer function of maximum bulk density $=$ Determinação da densidade relativa do solo por uma função de pedotransferência para a densidade do solo máxima. Acta Scientiarum Agronomy 33: 349-354 (in Portuguese).

Micucci, F.G.; Taboada, M.A. 2006. Soil physical properties and soybean (Glycine max, Merrill) root abundance in conventionallyand zero-tilled soils in the humid Pampas of Argentina. Soil and Tillage Research 86: 152-162.

Miura, K.A.; Iribarrem, P.C.; Chaves, R.D.; Cunha, H.N.; Pranke, L.V. 2015. Discrimination and Delimitation of the Lowlands in the State of Rio Grande do Sul: First Approach = Discriminação e Delimitação das Terras Baixas no Estado do Rio Grande do Sul: Primeira Aproximação. Embrapa, Pelotas, RS, Brazil (in Portuguese).

Moraes, M.T.; Debiasi, H.; Franchini, J.C.; Mastroberti, A.A.; Levien, R.; Leitner, D.; Schnepf, A. 2020. Soil compaction impacts soybean root growth in an Oxisol from subtropical Brazil. Soil \& Tillage Reserch 200: 1-14.

Nunes, M.R.; Denardin, J.E.; Pauletto, E.A.; Faganello, A.; Pinto, L.F.S. 2015. Mitigation of clayey soil compaction managed under no-tillage. Soil Tillage Research 148: 119-126.
Olibone, D.; Encide-Olibone, A.P.; Rosolem, C.A. 2010. Least limiting water range and crop yields as affected by crop rotations and tillage. Soil Use and Management 26: 485-493.

Ram, H.; Singh, Y.; Saini, K.S.; Kler, D.S.; Timsina, J. 2013. Tillage and planting methods effects on yield, water use efficiency and profitability of soybean-wheat system on a loamy sand soil. Experimental Agriculture 49: 524-542.

Rao, A.N.; Johnson, D.E.; Sivaprasad, B.; Ladha, J.K.; Mortimer, A.M. 2007. Weed management in direct-seeded rice. Advances in Agronomy 93: 153-255.

Reichert, J.M.; Suzuki, L.E.A.S.; Reinert, D.J.; Horn, R.; Håkansson, I. 2009. Reference bulk density and critical degreeof-compactness for no-till crop production in subtropical highly weathered soils. Soil and Tillage Research 102: 242-254.

Salvadori, J.R.; Bacaltchuk, B.; Deuner, C.C.; Lamas, G.L.C.J.; Rizzardi, M.A.; Lângaro, N.C.; Ecosteguy, P.A.V.; Boller, W. 2016. Techniques for the Cultivation of Soybeans in Rio Grande do Sul and Santa Catarina, Crops 2016/2017 and 2017/2018 = Indicações Técnicas para a Cultura da Soja no Rio Grande do Sul e Santa Catarina, Safras 2016/2017 e 2017/2018. Universidade de Passo Fundo, Passo Fundo, RS, Brazil (in Portuguese).

Sánchez-Llerena, J.; López-Piñeiro, A.; Albarrán, Á.; Peña, D.; Becerra, D.; Rato-Nunes, J.M. 2016. Short and long-term effects of different irrigation and tillage systems on soil properties and rice productivity under Mediterranean conditions. European Journal of Agronomy 77: 101-110.

Sartori, G.M.S.; Marchesan, E.; David, R.; Carlesso, R.; Petry, M.T.; Aires, N.P.; Giacomeli, R.; Aramburu, B.B.; Silva, A.L. 2016. Soybean tillage systems and physical changes in surface layers of two albaqualf soils. Revista Brasileira de Ciência do Solo 40: 1-15.

Silva, S.G.C.; Silva, A.P.; Giarola, N.F.B.; Tormena, C.A.; Sá, J.C.M. 2012. Temporary effect of chiseling on the compaction of a rhodic hapludox under no-tillage. Revista Brasileira de Ciência do Solo 36: 547-555.

Silva, F.R.; Albuquerque, J.A.; Costa, A. 2014. Initial growth of the soybean crop in an Oxisol with different degrees of compaction. Revista Brasileira de Ciência do Solo 38: 1731-1739 (in Portuguese, with abstract in English).

Six, J.; Bossuyt, H.; Degryze, S.; Denef, K. 2004. A history of research on the link between (micro) aggregates, soil biota, and soil organic matter dynamics. Soil and Tillage Research 79: 7-31.

Soil Survey Staff. 2014. Keys to Soil Taxonomy. 12ed. USDA-Natural Resources Conservation Service, Washington, DC, USA.

Steduto, P.; Hsiao, T.C.; Raes, D.; Fereres, E. 2009. AquaCrop: the FAO crop model to simulate yield response to water. I. Concepts and underlying principles. Agronomy Journal 101: 426-437.

Theisen, G.; Silva, J.J.C.; Silva, J.S.; Andres, A.; Anten, N.P.; Bastiaans, L. 2017. The birth of a new cropping system: towards sustainability in the sub-tropical lowland agriculture. Field Crop Research 212: 82-94.

Van Roekel, R.J.; Purcell, L.C.; Salmerón, M. 2015. Physiological and management factors contributing to soybean potential yield. Field Crop Research 182: 86-97.

Williams, S.M.; Weil, R.R. 2004. Crop cover root channels may alleviate soil compaction effects on soybean crop. Soil Science Society of America Journal 68: 1403-1409. 